\title{
Respon Pemberian Ekstrak Daun Mimba Azadirachta indica Pada Sistem Imun Ikan Nila (Oreochromis niloticus)
}

\section{Response of Neem Leaves Azadirchta indica Extract Immune System of (Oreochromis niloticus)}

\author{
Lutfi Hamzan Wari ${ }^{1 *}$, Ayu Adhita Damayanti ${ }^{1}$, Fariq Azhar ${ }^{1}$ \\ ${ }^{1}$ Laboratorium Mikrobiologi Fakultas Pertanian, Program Studi Budidaya Perairan, Universitas \\ Mataram, Jl. Pendidikan No, 37 Mataram, Nusa Tenggara Barat \\ *Email: nnurfadillah6@gmail.com
}

Received : 09 March 2020

Accepted : 11 April 2020

Publish : 31 April 2020

\begin{abstract}
Abstrak
Ikan nila (Oreochromis niloticus) merupakan spesies ikan air tawar yang banyak di budidayakan di daerah - daerah yang memiliki ketersedian air tawar dalam jumlah yang besar. Dalam usaha budidaya ikan nila sering terjangkit adanya penyakit ikan yang tidak jarang menggagalkan pertumbuhan dan kelangsungan hidup ikan sehingga mengakibatkan kematian pada ikan yang dibudidayakan (gagal panen). Penelitian ini bertujuan untuk menganalisis respon pemberian ekstrak daun mimba (Azadiracta indicida) pada sistem imun dan pertumbuhan ikan nila. Ikan diberi ekstrak daun mimba yang ditambahkan ke dalam pakan selama 45 hari pada wadah kontainer ukuran $54 \mathrm{~cm}$ x $37 \mathrm{~cm}$ x $29 \mathrm{~cm}$ masing-masing 10 ekor/wadah dengan volume 20 liter. Penelitian dilakukan dalam 5 perlakuan, kontrol + (Pakan komersil dan diinfeksi Aeromonas hydrophila $10^{6} \mathrm{cfu} / \mathrm{ml}$ sebanyak $0,1 \mathrm{ml} / \mathrm{ekor}$ ), kontrol - (pakan komersil infeksi bakteri), P1 (pakan dicampur $0,5 \%$ ekstak daun mimba dan diinfeksi bakteri), P2 (1\% ekstrak dan diinfeksi), P3 (2\% ekstrak dan diinfeksi). Hasil penelitian menunjukkan bahwa pemberian ekstrak daun mimba dengan dosis 1\% mampu mempertahankan SR sebesar 100\%, meningkatkan jumlah eritrosit ikan nila sebesar $15,0 \times 10^{5} \mathrm{sel} / \mathrm{ml}$ dan leukosit sebesar $15,0 \times 10^{4} \mathrm{sel} / \mathrm{ml}$ dan haemoglobin sebesar $6,0 \%$ dari total sel darah yang terdapat pada P4 yang berperan dalam sistem imun ikan nila. Berdasarkan hasil penelitian ini, ekstrak daun mimba dapat digunakan pada budidaya ikan nila sebagai imunostimulan karena dapat meningkatkan kelangsungan hidup, sel darah merah, sel darah putih dan haemoglobin.
\end{abstract}

Keyword : Ekstrak daun mimba, Aeromonas hydrophila, Ikan nila, Pakan.

\begin{abstract}
Tilapia (Oreochromis niloticus) is a species of freshwater fish that is widely cultivated in areas that have a large quantity of fresh water. In the cultivation of tilapia fish are often infected by fish diseases which not infrequently thwart the growth and survival of fish resulting in death of fish that are cultivated (crop failure). This study aims to analyze the response of giving neem leaf extract (Azadiracta indicida) to the immune system and growth of tilapia. The fish were given neem leaf extract which was added to the feed for 45 days in $54 \mathrm{~cm} \times 37 \mathrm{~cm} \times 29 \mathrm{~cm}$ containers each with 10 heads / container with a volume of 20 liters. The study was conducted in 5 treatments, control + (commercial feed and infected by Aeromonas hydrophila $10^{6} \mathrm{cfu} / \mathrm{ml}$ as much as $0.1 \mathrm{ml} /$ head), control - (commercial feed of bacterial infection), P1 (feed mixed with $0.5 \%$ extra neem leaves and infected with bacteria ), P2 (1\% extracted and infected), P3 (2\% extracted and infected). The results showed that administration of neem leaf extract at a dose of $1 \%$ was able to maintain SR by $100 \%$, increasing the number of erythrocyte tilapia by $15.0 \times 10^{5}$ cells $/ \mathrm{ml}$ and leukocytes by $15.0 \times 10^{4}$ cells / $\mathrm{ml}$ and hemoglobin by $6.0 \%$ of the total blood cells contained in P4 that play a role in the immune system of tilapia. Based on the results of this study, neem leaf extract can be used in tilapia aquaculture as an immunostimulant because it can improve survival, red blood cells, white blood cells and hemoglobin.
\end{abstract}

Keyword : Extract neem leaves, Aeromonas hydrophila, Tilapia, Feed. 


\section{PENDAHULUAN}

Kemudahan dalam budidaya ikan nila menjadi salah satu alasan sebagian besar para petani ikan untuk melakukan budidaya ikan nila. Ikan nila juga memiliki beberapa kelebihan diantaranya memiliki pertumbuhan yang cepat, tahan terhadap serangan penyakit dan mudah dalam beradaptasi dengan lingkungan.

Pertumbuhan ikan dipengaruhi oleh beberapa faktor yaitu faktor dari dalam dan faktor dari luar, adapun faktor dari dalam meliputi sifat keturunan, ketahanan terhadap penyakit dan kemampuan dalam memanfaatkan makanan, sedangkan faktor dari luar meliputi sifat fisika, kimia dan biologi perairan (Mulqan, 2017). Seiring dengan bertambahnya permintaan konsumen baik di dalam negeri dan di luar negeri sehingga terjadi peningkatan produksi ikan nila yang berakibat serangan patogen.

Purwaningsih dan Taukhid (2010) berpendapat bahwa, patogen bakteri adalah jenis yang sering menjadi kendala dalam budidaya ikan nila. Salah satu bakteri yang sangat umum menyerang ikan nila adalah bakteri Aeromonas hydrophila.

Pada umumnya penyakit yang menyerang ikan sangat sulit dan jarang bisa disembuhkan sehingga diperlukan suatu manajemen kesehatan ikan agar ikan tidak mudah terserang penyakit yang akan berakibat pada kerugian. Dalam penelitian Ayini (2014), mengenai efek antibakteri ekstrak daun mimba untuk mencegah penyakit Vibrio algynoliticus yang menyerang Udang windu menunjukkan konsentrasi ekstrak yang di gunakan (\%) yaitu 2,5; 5; 7,5; 10; dan 12,5. Dari hasil penelitian menunjukkan bahwa konsentrasi $12,5 \%$ ditandai dengan sudah tidak munculnya koloni bakteri Vibrio alginolyticus.

Menurut penelitian Ambarwati (2007), tanaman mimba dapat menghambat pertumbuhan bakteri Salmonella thyposa dan Staphylococcus aureus. Mekanisme tanaman mimba yang berpotensi sebagai antibakteri yaitu menghambat sintesis membran sel bakteri sehingga pertumbuhannya bisa dihambat. 
Daun mimba mengandung senyawa nimbin dan nimbidin yang merupakan senyawa alkoloid. Senyawa alkoloid ini memiiki kemampuan sebagai antibakteri. Mekanisme penghambatan dengan cara mengganggu komponen penyusun peptidoglikan pada sel bakteri, sehingga lapisan dinding sel tidak terbentuk secara utuh dan menyebabkan kematian sel (Robinson, 1995 dalam Mawardi, 2016).

Penggunaan ekstrak daun mimba sebagai anti bakteri merupakan salah satu alternatif yang perlu dikaji dan diuji lebih lanjut untuk mengetahui seberapa besar pengaruh ekstrak daun mimba terhadap bakteri Aeromonas hydrophila yang menyerang ikan nila yang dibudidayakan di perairan tawar. Oleh karena itu, dalam pencegahan penyakit ikan nila akibat serangan bakteri Aeromonas hydrophila sangat penting dilakukan mengingat ganasnya serangan bakteri ini pada sebagian besar ikan nila yang dibudidayakan.

Selain itu, pemberian bahan alami dengan dosis yang tepat berpengaruh pada kesehatan ikan melalui tindakan pencegahan serangan Aeromonas hydrophila yang terjadi pada ikan nila. Penelitian ini bertujuan untuk menganalisis respon pemberian ekstrak daun mimba (Azadiracta indicida) pada sistem imun ikan nila (Oreochromis niloticus).

\section{METODE PENELITIAN Waktu dan Tempat}

Penelitian ini dilaksanakan selama 45 hari yaitu dari 2 Oktober sampai 16 November 2019.

\section{Persiapan Wadah dan Ikan Uji}

Wadah yang digunakan pada penelitian ini adalah box container ukuran 54 x 37 x 29 cm sebanyak 15 buah. Wadah diisi air tawar sebanyak 20 liter. Benih Ikan nila yang digunakan berat rata-rata 30 gram per ekor dan diadaptasi selama 7 hari di dalam wadah pemeliharaan sebanyak 10 ekor/container. Penyiponan dilakukan sebanyak satu kali sehari.

\section{Persiapan Pakan Ikan}

Pakan yang digunakan dalam pemeliharaan adalah pelet komersil dari CP. Prima dengan merek Hi Pro Vit 782 - 2 yang memiliki kandungan protein sebanyak 28$30 \%$. Jumlah pakan yang diberikan 
ditentukan dengan menghitung bobot biomassa pada ikan dan dikali dengan persentase kebutuhan pakan sebanyak $4 \%$. Pemberian pakan pada ikan dilakukan sebanyak 3 kali yaitu pada pagi, siang dan sore hari.

\section{Perlakuan}

Perlakuan yang diberikan yakni dengan penambahan ekstrak daun mimba Azadiracta indicida berdasarkan jumlah pakan dengan berbagai kombinasi yakni kontrol + (Pakan komersil dan diinfeksi Aeromonas hydrophila $10^{6} \mathrm{cfu} / \mathrm{ml}$ sebanyak 0,1 ml/ekor), kontrol (pakan komersil infeksi bakteri), P1 (pakan dicampur 0,5\% ekstak daun mimba dan diinfeksi bakteri), P2 (1\% ekstrak dan diinfeksi), P3 (2\% ekstrak dan diinfeksi). Selanjutnya ikan diinfeksi dengan bakteri Aeromonas hydrophila (Mulyani, 2013).

\section{Prosedur Kerja}

Pembuatan ekstrak penelitian ini dilakukan dengan metode maserasi menggunakan etanol dan dilakukan evaporasi dengan Rotary
Vacum Evaporator pada suhu $40^{\circ} \mathrm{C}$ sampai diperoleh ekstrak pekat dengan konsentrasi 100\% (Putri, 2015). Tahap selanjutnya, dilakukan pemeliharaan ikan nila selama 30 hari selanjutnya diinfeksi bakteri Aeromonas hydrophila dan pengamatan parameter dilakukan pada 7 hari pascainfeksi.

\section{Analisis Data}

Data parameter Sel Darah Merah, Haemoglobin Sel Darah Putih dan Kelangsungan Hidup menggunakan one way-analisis of variance dengan SPSS (Versi 16.0) pada taraf kepercayaan 95\% $(\mathrm{P}<0,05)$. Jika hasil berbeda nyata maka dilakukan uji lanjut dengan Tukey HSD.

\section{HASIL DAN PEMBAHASAN}

\section{Hasil Sel Darah Merah}

Berdasarkan hasil analisis varian dan uji lanjut Tukey diperoleh bahwa, ekstrak daun mimba dengan dosis berbeda berpengaruh terhadap jumlah sel darah merah (Eritrosit) disajikan pada (Gambar 1a). 

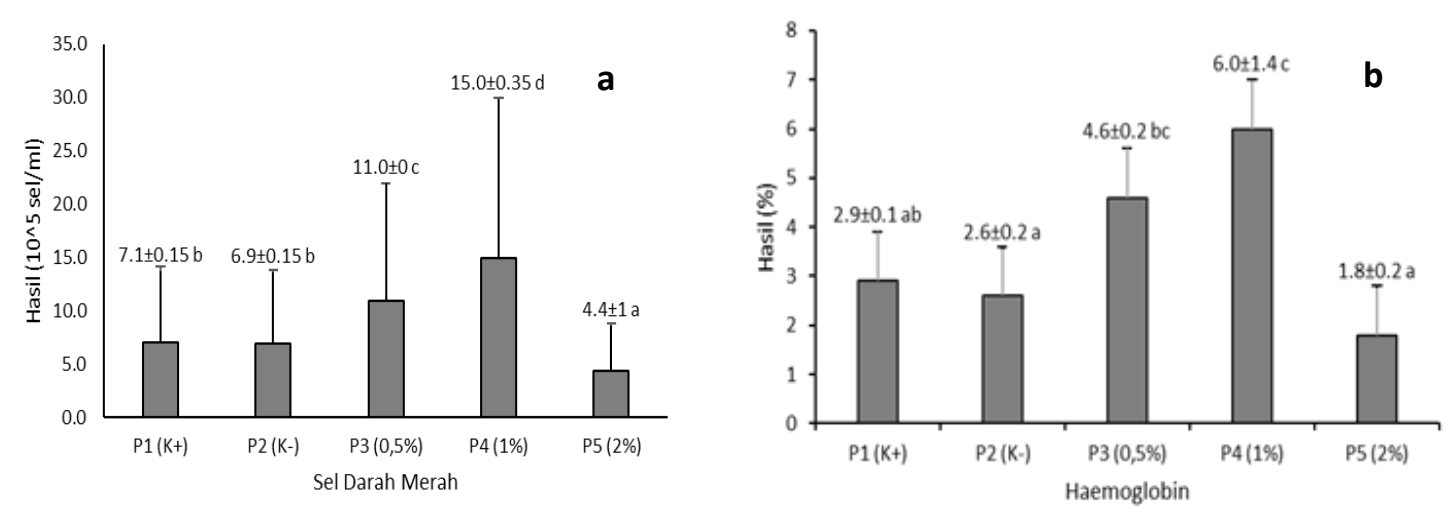

Gambar 1. (a): Sel darah merah ikan pasca uji tantang dengan Aeromonas hydrophila, (b): Haemoglobin ikan pasca uji tantang dengan Aeromonas hydrophila

Berdasarkan tabel diatas, terlihat bahwa pada P1 dan P2 yang berbeda dengan P3, P4 dan P5 diketahui P1 dan P2 tidak berbeda nyata. Adapun P3, P4 dan P5 ketiganya memberikan pengaruh nyata pada $(\mathrm{P}>0,05)$ pada jumlah sel darah merah. Hasil uji Tukey menunjukkan bahwa: P1 berbeda nyata dengan $\mathrm{P} 3, \mathrm{P} 4, \mathrm{P} 5$ namun tidak berbeda nyata dengan P2. Adapun P3, P4 dan P5, ketiganya berbeda nyata.

\section{Haemoglobin}

Hasil analisis statistik dengan uji One-Way Annova menunjukkan bahwa pemberian ekstrak daun mimba berpengaruh signifikan $(\mathrm{P}<0,05)$ pada jumlah haemoglobin. P1 tidak berbeda nyata dengan $\mathrm{P} 2$, P3, P5 namun berbeda nyata dengan
P4. Hasil uji lanjut tukey menunjukkan perbedaan jelas terutama pada P2 dan P4, dimana P2 dan P5 tidak berbeda nyata. Adapun P2 tidak berbeda nyata dengan P5, begitupula dengan P1, P2, P3 dan P5 (Gambar 1b).

\section{Sel Darah Putih}

Hasil analisis statistik dengan uji One-Way Annova menunjukkan bahwa pemberian ekstrak daun mimba berpengaruh signifikan $(\mathrm{P}<0,05)$ dalam meningkatkan nilai sel darah putih. Hasil uji Tukey menunjukkan P1 berbeda nyata dengan semua perlakuan yang diberi ekstrak daun mimba dan kontrol negatif. Namun demikian pada P4 tidak berbeda nyata dengan P5 (Gambar 3a). 

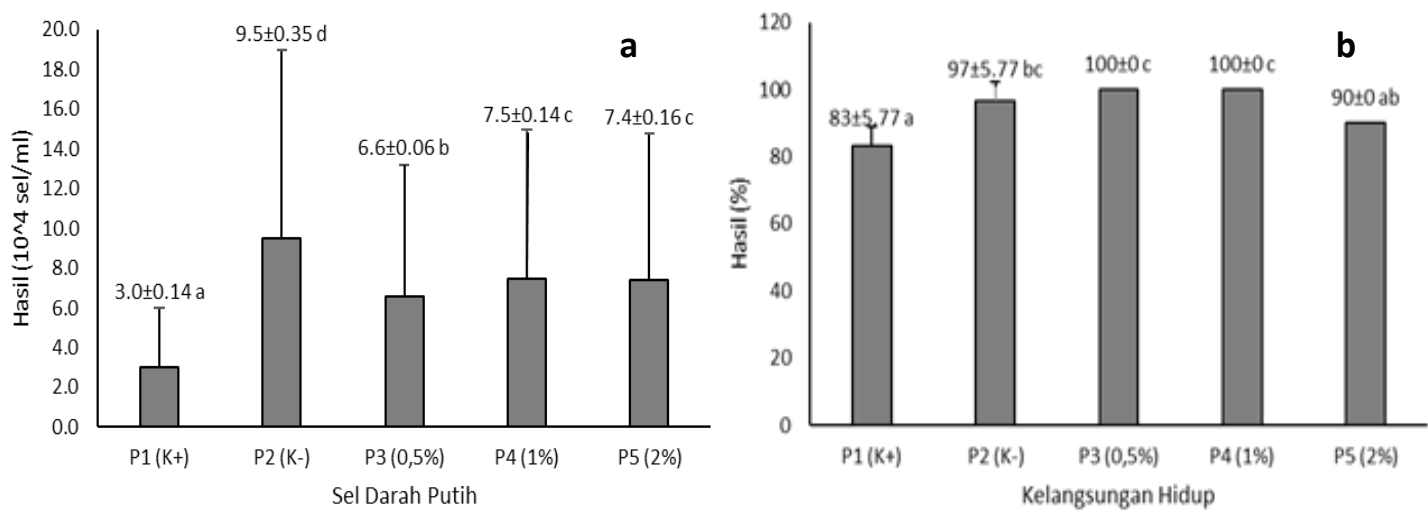

Gambar 3. (a): Sel darah Putih ika pasca uji tantang dengan Aeromonas hydrophila, (b): Kelangsungan Hidup ikan pasca uji tantang dengan Aeromonas hydrophila

\section{Kelangsungan Hidup}

Hasil analisis statistik dengan uji One-Way Annova dan uji lanjut Tukey menunjukkan bahwa pemberian ekstrak daun mimba memberikan pengaruh signifikan $(\mathrm{P}<0,05) \quad$ terhadap tingkat kelangsungan hidup ikan yang diinfeksi bakteri Aeromonas hydrophila. Respon yang berbeda nyata terlihat jelas pada ikan yang infeksi tanpa ekstrak (P1) dengan ikan yang mendapatkan perlakuan ekstrak daun mimba (P3 dan P4). Adapun perlakuan dosis tertinggi (P5) tidak berbeda nyata dengan perlakua ikan yang diinfeksi tanpa ekstrak daun mimba (P1) dan perlakuan ikan yang tidak diinfeksi (P2) bakteri Aeromonas hydrophila. Adapun P3 dan P4 tidak berbeda nyata dengan P2 (Gambar 3b).

\section{PEMBAHASAN}

Pengamatan jumlah eritrosit atau sel darah merah selama penelitian dilakukan pada akhir penelitian (Gambar 1). Injeksi bakteri tidak menurunkan jumlah sel darah merah, terlihat dari P1 yang tidak berbeda nyata dengan P2. Penambahan ekstrak daun mimba efektif meningkatkan sel darah merah, terlihat pada P3 dan P4 yang berbeda nyata dengan P2 dan P1. Jumlah sel darah merah pada P4 yaitu $15.0 \times 10^{5} \mathrm{sel} / \mathrm{ml}$ merupakan jumlah sel darah merah tertinggi. Untuk dosis ekstrak daun mimba pada P5 tidak dapat dipakai, terlihat pada P5 yang berbeda nyata dengan P2. Daun mimba dengan dosis $2 \%$ pada P5 justru dapat menurunkan jumlah sel darah merah. Menurut pendapat Hartika et,.al (2014) yang 
menjelaskan bahwa kisaran normal jumlah eritrosit ikan pada umumnya yaitu 20.000-3.000.000 sel/ml.

Sel darah merah berfungsi sebagai penyalur makanan di dalam tubuh dan pengedar oksigen dalam tubuh ikan. Jumlah sel darah merah mengindikasikan bentuk perlawanan tubuh terhadap serangan benda asing yang dirangsang oleh adanya imunostimulan. Selain itu juga menurut Rahma et,.al (2015), sel darah merah mengandung hemoglobin yang memungkinkan sel darah merah membawa oksigen ke seluruh jaringan tubuh. Rendahnya eritrosit akan menyebabkan ikan tidak mampu mengambil oksigen dalam jumlah banyak walaupun ketersedian oksigen di perairan mencukupi. Agusty et al (2018) menambahkan, tanaman mimba merupakan salah satu tanaman yang memiliki kandungan senyawa seperti azadirachtin, tanin, gallic acid, polyphenol dan senyawa lainnya.

\section{Polyphenol merupakan} senyawa yang memiliki kemampuan untuk merusak membran sel dari parasit sehingga mampu menekan jumlah bakteri di dalam darah sehingga jumlah eritrosit mampu dipertahankan. Melalui pemberian ekstrak daun mimba sebagai imunostimulan sehingga meningkatkan jumlah sel darah merah sebagaimana mekanisme kerja imunostimulan apabila imunostimulan masuk ke dalam tubuh maka imunostimulan akan merangsang makrofag untuk memproduksi interleukin yang akan menggiatkan sel limfosit yang kemudian membelah menjadi limfosit $\mathrm{T}$ dan limfosit $\mathrm{B}$.

Selanjutnya limfosit $\mathrm{T}$ akan memproduksi interferon yang mampu membangkitkan kembali makrofag, sehingga dapat memfagosit bakteri, virus, dan partikel asing lainnya yang masuk ke dalam tubuh (Raa, 2000 dalam Mas'ud, 2013). Pada hasil penelitian respon imun belum terlihat karena tidak ada penurunan sel darah merah pada P1. Namun demikian, ekstrak daun mimba dapat meningkatkan jumlah sel darah merah. Hal ini terlihat dari nilai sel darah merah pada P4 yang jauh lebih tinggi dibandingkan $\mathrm{P} 2$.

$$
\text { Haemoglobin merupakan }
$$
pigmen dalam darah yang memberikan warna merah pada 
darah. Hemoglobin merupakan protein dalam eritrosit yang tersusun atas protein globin tidak berwarna. Berdasarkan Gambar 2. Jumlah haemoglobin pada P4 merupakan jumlah paling tinggi diantara semua perlakuan yaitu $6,0 \%$. Injeksi bakteri dengan kepadatan $10^{6} \mathrm{sel} / \mathrm{ml}$ tidak menurunkan jumlah haemoglobin, terlihat dari P1 yang tidak berbeda nyata dengan P2. Penambahan ekstrak daun mimba efektif meningkatkan haemoglobin, terlihat pada $\mathrm{P} 4$ sebesar 6,0 \% dibandingkan dengan P2 dan P1 masing-masing sebesar 2,6\% dan 2,9\%. Untuk dosis ekstrak daun mimba pada P5 tidak efektif, terlihat pada nilai haemoglobin P5 (1,8\%) yang tidak berbeda nyata dengan P2 dan P1. Oleh karena itu, dapat dikatakan bahwa yang dihasilkan dalam eritrosit dapat meningkatkan kemampuan darah mengangkut oksigen. Sementara jumlah haemoglobin yang paling rendah terdapat pada P5 sebesar 1,8\%, sehingga mengindikasikan ekstrak dapat jumlah yang besar tidak selalu berdampak baik bagi kesehatan ikan khususnya pada kandungan haemoglobin dalam darah yang dapat mempengaruhi proses pengangkutan oksigen dalam darah. Menurut Hardi et al, (2011) dalam Kurniawan (2019) bahwa kadar rata-rata $\mathrm{Hb}$ ikan nila normal berkisar $6-11,01(\mathrm{~g} \%)$. Terjadinya penurunan kadar hemoglobin setelah infeksi bakteri dalam darah ikan nila, dan selanjutnya darah akan melakukan mekanisme fagositosis sebagai bentuk perlawanan terhadap bakteri patogen.

Jumlah leukosit atau sel darah putih menunjukkan bahwa terdapat perbedaan hampir pada setiap perlakuan. Injeksi bakteri dengan kepadatan $10^{6} \mathrm{sel} / \mathrm{ml}$ menurunkan jumlah sel darah putih, terlihat dari P1 yang berbeda nyata dengan P2. Penambahan ekstrak daun mimba efektif untuk meningkatkan sel darah putih ikan yang diinfeksi bakteri, terlihat pada P3 $\left(6,6 \times 10^{4} \mathrm{sel} / \mathrm{ml}\right), \mathrm{P} 4$ $\left(7,5 \times 10^{4} \mathrm{sel} / \mathrm{ml}\right)$ dan P5 $\left(7,4 \times 10^{4}\right.$ $\mathrm{sel} / \mathrm{ml})$ yang berbeda nyata dengan kenaikan P1 $\left(3,0 \times 10^{4} \mathrm{sel} / \mathrm{ml}\right)$. Namun demikian, penggunaan dosis ekstrak daun mimba hingga 2\% masih belum dapat mengembalikan ke nilai normal ikan sebelum diinfeksi bakteri. Rastogi (1977) dalam Sani (2014) melaporkan 
bahwa jumlah leukosit terbaik ikan berkisar antara 20.000-150.000 $\mathrm{sel} / \mathrm{ml}$.

Oleh karena itu, walaupun penggunaan ekstrak daun mimba belum mampu kembali pada jumlah sel darah putih ikan yang tidak diinfeksi, maka penggunaan ekstrak ini masih dapat direkomendasikan. Hartika et al. (2014), bahwa indikasi penurunan leukosit dapat berdampak negatif pada ikan karena kekebalan tubuh dapat menurun. Peningkatan jumlah leukosit dapat berperan cukup besar terhadap peningkatan respon imun atau ketahanan tubuh ikan nila dari serangan penyakit dan infeksi. Jumlah leukosit yang hampir meningkat pada ikan nila yang terinfeksi bakteri seiring dengan bertambahnya jumlah ekstrak yang ditambahkan sebagai imunostimulan bagi ikan. Salah satu kemampuan imunostimulan adalah dapat meningkatkan ketahanan tubuh ikan yaitu dengan meningkatnya sel-sel fagositosis. Sel-sel fagositosis ini berfungsi melakukan fagositosis terhadap benda-benda asing yang masuk ke tubuh inang (Raa, 2000 dalam Mas'ud, 2013).
Kelangsungan hidup ikan nila tertinggi terdapat pada P3 dan P4 yaitu 100\% (Gambar 4). Injeksi bakteri menyebabkan tingkat kelangsungan hidup ikan nila menurun terlihat pada P2 yang berbeda nyata dengan P1. Penggunaan ekstrak daun mimba efektif meningkatkan kelangsungan hidup, terlihat pada nilai P3 dan P4 yang berbeda nyata dengan P1 (kontrol). Penambahan ekstrak daun mimba ini juga efektif meningkatkan kelangsungan hidup ikan nila kembali pada kondisi normal tanpa injeksi bakteri, terlihat pada P2 (97\%) yang tidak berbeda nyata dengan P3 (100\%) dan P4 (100\%). Adapun P5 (90\%) adalah dosis yang tidak efektif, hal ini terlihat pada nilai kelangsungan hidup P5 yang tidak berbeda nyata dengan P1, dimana P1 tidak diberikan ekstrak daun mimba.

Penambahan ekstrak daun mimba pada pakan dapat memberikan dampak pada peningkatan kelangsungan hidup ikan nila yang terinfeksi bakteri, karena diketahui memiliki manfaat sebagai antibakteri terhadap bakteri gram positif dan bakteri gram negatif 
(Saradhajyoti et al, 2011 dalam Ayini, 2014). Sementara pada P2 merupakan kontrol negatif yang tidak diberi ekstrak dan tidak diinjeksi sehingga kematian ikan berkurang karena faktor lingkungan seperti ikan terlalu aktif sehingga lompat keluar dari wadah. Sedangkan untuk P5 yang diberi ekstrak 2\% dan diinjeksi bakteri menurunkan tingkat kelangsungan hidup.

Hal tersebut diduga akibat jumlah ekstrak yang banyak sehingga menyebabkan perubahan pada rasa dan aroma pakan sehingga mempengaruhi jumlah pakan yang dimakan akibatnya pada saat diinfeksi bakteri ikan tersebut tidak memiliki daya tahan yang cukup baik untuk melawan bakteri yang diinfeksikan tersebut. Pada P5 ini juga di beberapa parameter diperoleh hasil yang kurang maksimal. Menurut Raharjo (2014), faktorfaktor yang mempengaruhi tingkat kelangsungan hidup suatu organisme kualitas air, abiotik, kompetisi antara jenis, kekurangan pakan, penambahan populasi dalam ruang lingkungan yang sama, parasit dan penyakit, penanganan manusia, umur organisme dan kemampuan adaptasi terhadap lingkungan. Menurut Kurniawan (2019), jumlah Aeromonas hydrophila yang diinjeksikan juga mempengaruhi tingkat kelangsungan hidup dan gejala klinis yang timbul pasca infeksi bakteri.

\section{KESIMPULAN}

Ekstrak daun mimba Azadirachta indica efektif dalam meningkatkan sistem imun. Pemberian ekstrak daun mimba Azadirachta indica berpengaruh signifikan pada kesehatan ikan nila yang terinfeksi bakteri Aeromonas hydrophila. Pemberian ekstrak daun mimba dengan dosis $0,5 \%(\mathrm{P} 3)$ dan $1 \%$ (P4) mampu meningkatkan kelangsungan hidup hingga $100 \%$. Pemberian ekstrak daun mimba ini dapat menjadi imunostimulan bagi ikan nila jumlah sel darah merah tertinggi sebesar $15,0 \times 10^{5} \mathrm{sel} / \mathrm{ml}$, pada perlakuan dosis $1 \%(\mathrm{P} 4)$, dan juga sel darah putih tertinggi yaitu pada dosis $1 \%$ dan $2 \%$ yaitu masingmasing sebesar $7,5 \times 10^{4} \mathrm{sel} / \mathrm{ml}$ dan $7,4 \times 10^{4} \mathrm{sel} / \mathrm{ml}$ dengan haemoglobin masing-masing sebesar $4,6 \%$ dan $6,0 \%$ dari total sel darah yang terdapat pada $\mathrm{P} 4$ dengan dosis 
Journal of Aquaculture Science

DOI: https://doi.org/10.31093/joas.v5i1.83

ekstrak 1\%. Penggunaan dosis tertinggi $2 \%$ (P5) tidak efektif dalam meningkatkan kelangsungan hidup dan dapat menurunkan jumlah sel darah merah.

\section{Ucapan Terima Kasih}

Penulis mengucapkan terimakasih Kepada Dosen Pembimbing serta institusi perguruan tinggi dalam hal ini Universitas Mataram sebagai tempat peneliti menimba ilmu dan pengetahuan serta rekan-rekan seperjuangan.

\section{DAFTAR PUSTAKA}

Agusty, A., Fahrimal, Y., Lubis, T. M., Hambal, M., Zuhrawati, N.A \& Sayuti, A. (2018). The Effect Of Neem Leaves (Azadirachta Indica) Extract to The Blood Profile of Male Rat (Rattus Norvegicus) Infected with Trypanosoma Evansi of Krueng Raya Isolat. Jurnal Medika Veterinaria 12 (1): $70-76$.

Ambarwati. (2007). Efektivitas zat antibakteri biji mimba (Azadirachta indica) untuk Menghambat Pertumbuhan Salmonella thyposa dan Staphylococcus aureus. Journal Biodiversitas 8(3): 320-325.

Ayini U., Siti, H.B \& Titis, C.D. (2014). Efek Antibakteri Ekstrak Daun Mimba
April 2020 vol 5 (1): 8-19

Online pada http://joas.co.id

(Azadirachta indica A. Juss) terhadap Bakteri Vibrio algynoliticus Secara In Vitro. Biosaintifika 6 (1).

Hartika, R., Mustahal \& Putra, A. N. (2014). Gambaran Darah Ikan Nila (Oreochromis niloticus) dengan Penambahan Dosis Prebiotik yang Berbeda Dalam Pakan. Jurnal Perikanan dan Kelautan 4 (4) : $259-267$.

Kurniawan, A. P., Suminto \& Haditomo, A. H. C. (2019). Pengaruh Penambahan Bakteri Kandidat Probiotik Bacillus methylothropicus pada Pakan Buatan Terhadap Profil Darah dan Performa Pertumbuhan Ikan Nila (Oreochromis niloticus) yang Diuji Tantang dengan Bakteri Aeromonas hydrophila. Jurnal Sains Akuakultur Tropis 3 (1): 82 - 92 .

Mas'ud, F. (2013). Efektifitas Candida sp. sebagai Imunostimulan pada Ikan Lele Dumbo (Clarias gariepenus) terhadap Infeksi Aeromonas hidrophylla. Jurnal Ilmu Eksakta 1.

Mawardi, M. (2016). Srategi Perbaikan Kesehatan Ikan Nila

(Oreochromis niloticus) Melalui Pemberian Fitofarmaka. Program Pascasarjana Universitas Terbuka, Jakarta. 
Mulqan, M., Rahimi, S. A. E \& Dewiyanti, I. (2017). Pertumbuhan dan Kelangsungan Hidup Benih Ikan Nila Gesit (Oreochromis niloticus) Pada Sistem Akuaponik Dengan Jenis Tanaman Yang Berbeda. Jurnal Ilmiah Mahasiswa Kelautan Unsyiah 2 (1) : 183 - 193.

Mulyani. Y., Bachtiar. E \& Kurnia M. U,. (2013). Peranan senyawa metabolik sekunder tumbuhan mangrove terhadap infeksi bakteri Aeromonas hydrophila pada ikan mas (Cyprinus carpio

Raharjo, E. I. (2014). Efektifitas Ekstrak Rumput Laut (Sargassum Polycystum) sebagai Antibakteri pada Ikan Mas (Cyprinus Carpio) yang Terinfeksi Bakteri
Aeromonas Hydrophila.

Jurnal ruaya 4: 2541 3155 .

Rahma, W.F., G. Mahasri., L. Surmartiwi. (2015). Pengaruh Pemberian Ekstrak Sargassum sp. dengan Pelarut Metanol pada Pakan Terhadap Jumlah Eritrosit dan Differensial Leukosit Ikan Lele Dumbo (Clarias gariepinus). Jurnal Ilmiah Perikanan dan Kelautan 7 (2).

Sani. A. (2014). Pengaruh Penambahan Fukoidan pada Pakan terhadap Respon Imun Non Spesifik

Taukhid, Suharni I dan Supriyadi, H,. (2007). Efektivitas Daun Sambiloto (Andrographis paniculata). Jurnal Akuakultur 2 (3) : 411-41. 